\title{
Traffic Congestion Index and Level Estimation using Two Phase Fuzzy Controller
}

\author{
${ }^{* 1}$ Prof. Prachiti Pimple, ${ }^{2}$ Prof. Gajanan Babhulkar, ${ }^{3}$ Prof. Bhumesh Masram, ${ }^{4}$ Prof. Payal Jadhav, ${ }^{5}$ Prof. \\ Suraj Bandichode \\ ${ }^{1}$ K.K. Wagh Institute of Engineering Education and Research, Nashik, \\ ${ }^{2}$ Dr. D. Y. Patil College of Engineering, Pune, \\ ${ }^{3}$ PICT, Pune, \\ ${ }^{4}$ PES Modern College of Engineering, Pune, \\ ${ }^{5} \mathrm{G}$ H Raisoni College of Engineering Nagpur \\ *Email: pspimple@kkwagh.edu.in.
}

\section{Received: $0^{\text {th }}$ July 2018, Accepted: $14^{\text {th }}$ August 2018, Published: $31^{\text {st }}$ August 2018}

\begin{abstract}
Many measures have been proposed to represent the status of traffic conditions on arterial roadways in urban areas. Traffic congestion is rising nowadays and to understand its nature, a systematic mechanism is required. A new approach is presented in this research work to measure the congestion index first and then the congestion level. In this research work, a twophase fuzzy controller is applied wherein in first phase the traffic congestion index is measured by using travel speed rate and very-low speed rate followed by congestion level measurement by using density state and congestion index in next phase. The application of the proposed approach is demonstrated using realworld data of small area segment of Nagpur city, India. The outcome was a single congestion index value between 0 and 1 , where 0 is the best condition and 1 is the worst condition.
\end{abstract}

Keywords: Traffic Congestion Level Estimation, Congestion Index, Travel Speed Rate, Very-Low Speed Rate

\section{Introduction}

Traffic congestion is rising nowadays and to understand its nature, a systematic mechanism is required. A new approach is presented in this research work to measure the congestion index first and then the congestion level. A two-phase fuzzy controller is applied wherein in first phase the traffic congestion index is measured by using travel speed rate and verylow speed rate followed by congestion level measurement by using density state and congestion index in next phase. The application of the proposed approach is demonstrated using real-world data of small area segment of Nagpur city, India. Problems need to be considered while measuring congestion are described next, Measurements and observations are approximate. Imprecision exists in both demand-side and supply-side. Intersection signal timings and geometric design parameters from supply-side, varying delay and travel time from demand-side are not precise and hence accuracy in measuring congestion is associated with the uncertainty.

Acceptable speed condition changes depending on traveler's experience and roadway condition; if the path segment geometry is good then travelers feel that acceptable speed is high and if the path segment geometry is poor then travelers feel that acceptable speed is low.

A use of Level-of-Service (LOS) is misleading sometimes when the condition is nearer to threshold. A small change in the input makes significance difference in output.

In general, the congestion is caused by various factors and is perceived in several ways. Hence the degree of congestion determining process which involves the subjective notion of acceptability and imprecise quantities are inevitable. The proposed two phase fuzzy controller for traffic congestion level measuring, will consist of measuring of congestion index by considering two parameters namely travel speed rate and very-low speed rate, followed by congestion level measuring using traffic density state and previously measured congestion index. In the first phase, the two input measures are computed separately based on real-world data and then combined using fuzzy inference rules. The travel speed rate is defined as rate of reduction in the speed which is caused by congestion from free-flow speed condition

Travel Speed Rate $=($ Free Flow Speed- Average Speed ) / Free Flow Speed

Travel speed rate takes value in range 0 and 1 , wherein 0 indicates best condition wherein average speed is greater than or equal to free-flow speed and 1 indicate worst condition.

Very-low speed rate is proportion of time spent in delay to the total travel time. It takes value in the range 0 and 1 , where 0 indicate best condition with no delay and 1 indicate worst condition with time spent in delay conditions. 
Helix Vol. 8(5): 4029- 4033

Very Low Speed Rate $=$ Time Spent in Delay $/$ Total Travel Time

The travel speed rate is categorized from A through $\mathrm{F}$, where $\mathrm{A}$ is best and $\mathrm{F}$ is worst. The correspondence between fuzzy sets and values is based on Highway Capacity Manual (HCM 2000) definition of Level of Service for urban arterials. Similarly, the very-low speed rate is categorized into groups of low, moderate and high where low indicate the proportion of travel time at very low speed is minimum and hence good condition. Based on travel speed rate and very-low speed rate, the congestion index is measured as output and it is categorized as low, moderate, high and very high (Kittelson and Roess, 2001).

\section{Study Area}

An area segment of Nagpur city from Hingna T-point to Variety Square is considered for this study. The considered area segment is shown in figure 1, Total 31 signalized intersections were considered and about 40 links were analyzed. To manage the overall study of above area segment only signalized intersections were considered

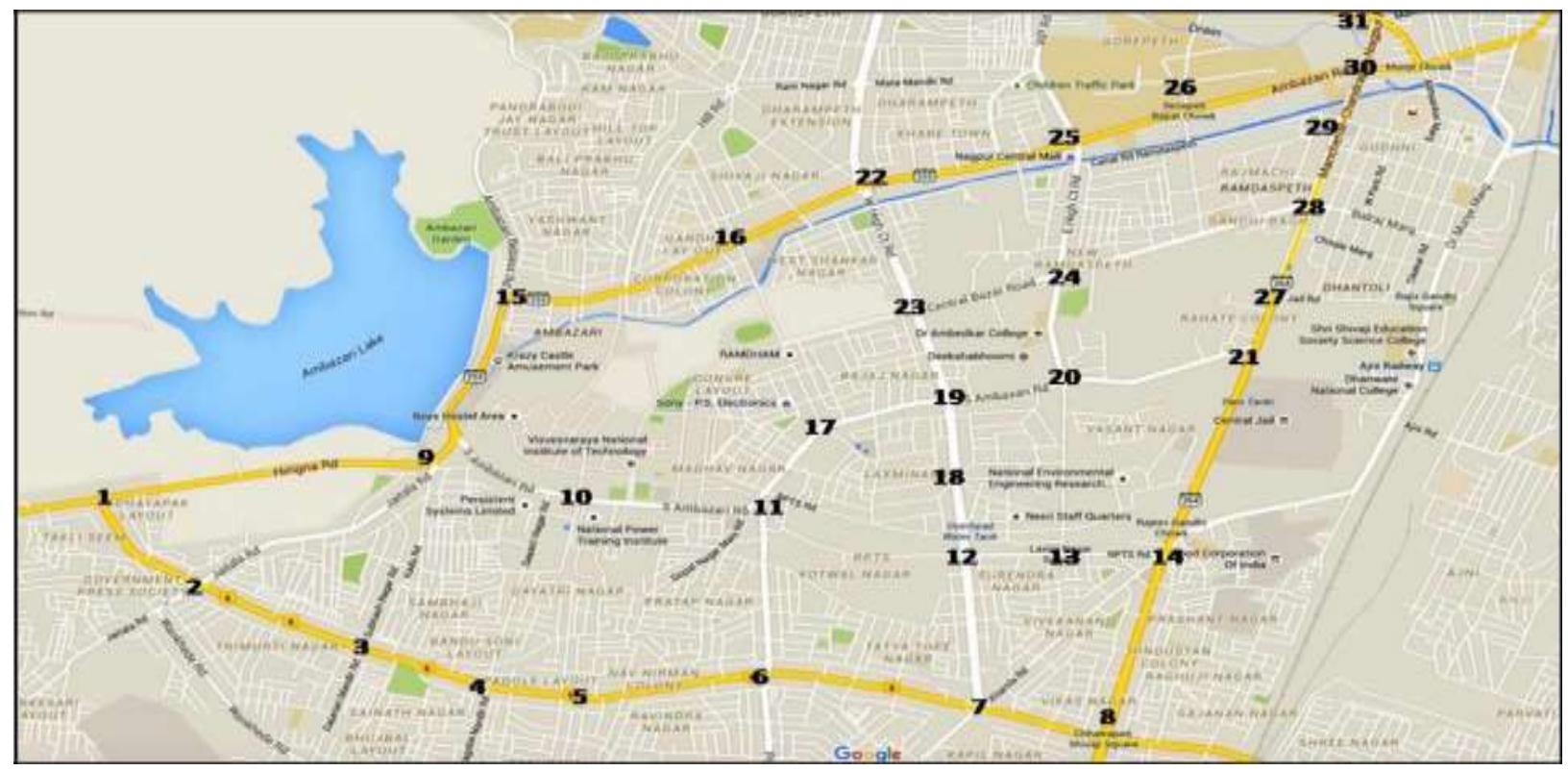

Figure 1. Area Segment of Nagpur City (from Hingna T-point to Variety Square) for Study

\begin{tabular}{|r|l|l|l|}
\hline $\begin{array}{l}\text { Intersection } \\
\text { Number }\end{array}$ & Intersection Name & $\begin{array}{l}\text { Intersection } \\
\text { Number }\end{array}$ & Intersection Name \\
\hline 1 & Ambazari T -Point & 17 & Shradhanand Peth/Abhynkar nagar Square \\
\hline 2 & Mangalmurti Square & 18 & Eight Road Square \\
\hline 3 & Trimurti Nagar Square & 19 & Lakshmi Nagar Square \\
\hline 4 & Gayatri Nagar Square & 20 & Dikshabhoomi Square \\
\hline 5 & Padole Hospital Square & 21 & Central Jail Square \\
\hline 6 & Pratap Nagar Square & 22 & Shankar Nagar Square \\
\hline 7 & Khamla Square & 23 & Bajajnagar Square \\
\hline 8 & Chatrapati Square & 24 & Kachipura Square \\
\hline 9 & Subhash Nagar Square & 25 & Alankar Talkies Square \\
\hline 10 & V.N.I.T Square & 26 & University Library Square \\
\hline 11 & Mate Square & 27 & Rahate Colony Square \\
\hline 12 & RPTS square & 28 & Lokmat Square \\
\hline 13 & NEERI Square & 29 & Panchasheel Square \\
\hline 14 & Ajni Square & 30 & Jhansi Rani Square \\
\hline 15 & Dharampeth Science College Square & 31 & Variety Square \\
\hline 16 & LAD College/Gandhi Nagar Square & \\
\hline
\end{tabular}

Table I. Intersections on the Considered Study Area 


\section{Fuzzy Controller Design}

For travel speed rate, the calculated value is translated into one of six natural-language-based classes from very good (near 0 ) to very bad (near 1 ). The six categories are designated $\mathrm{A}$ to $\mathrm{F}$, for ease of designation: $\mathrm{A}$ is the best, and $\mathrm{F}$, the worst. The correspondence between the values and the fuzzy sets is based on the HCM 2000 definition of LOS for urban and suburban arterials. The membership functions corresponding to each of these classes are shown in Figure 2, in where a value of speed reduction rate is given, the degree to which this value is compatible with a class is given in the membership function. It is possible that one value could correspond to more than one class.

The values of very-low-speed rate are categorized into three groups that are identifiable to travellers: "low," "moderate," and "high," where "low" indicates that the proportion of travel time at very low speeds (less than $5 \mathrm{kmph}$ ) is minimal and thus the condition is very good. The membership functions of the three classes are shown in Figure 3.

Output Parameter: The quantification of congestion in terms of "congestion index" is the output of the process, is categorized into four classes: "low," "moderate," "high," and "very high." Their membership functions are shown in Figure 4, in which the $\mathrm{x}$-axis is a scale between 0 and 1 , where 0 , is very good, and 1 is very bad. The four classes of congestion condition are defined on the basis of this scale. The boundaries of the classes are rather vague, and hence each class is designated with a natural-language term, which is useful in expressing the prevailing situation (Khatib and Kyte, 2001).

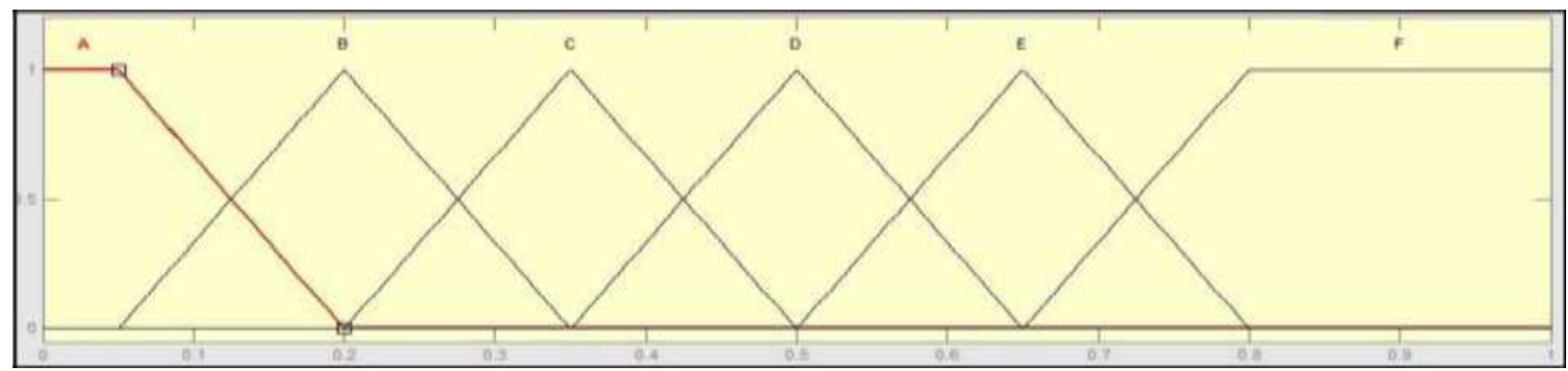

Figure 2. Membership Functions of Travel Speed Rate

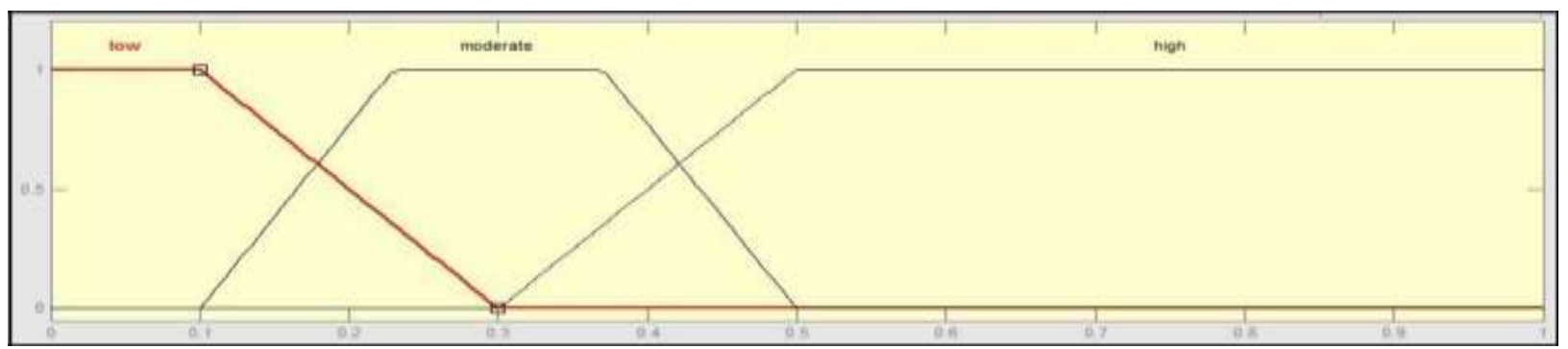

Figure 3. Membership Functions of Very Low Speed Rate

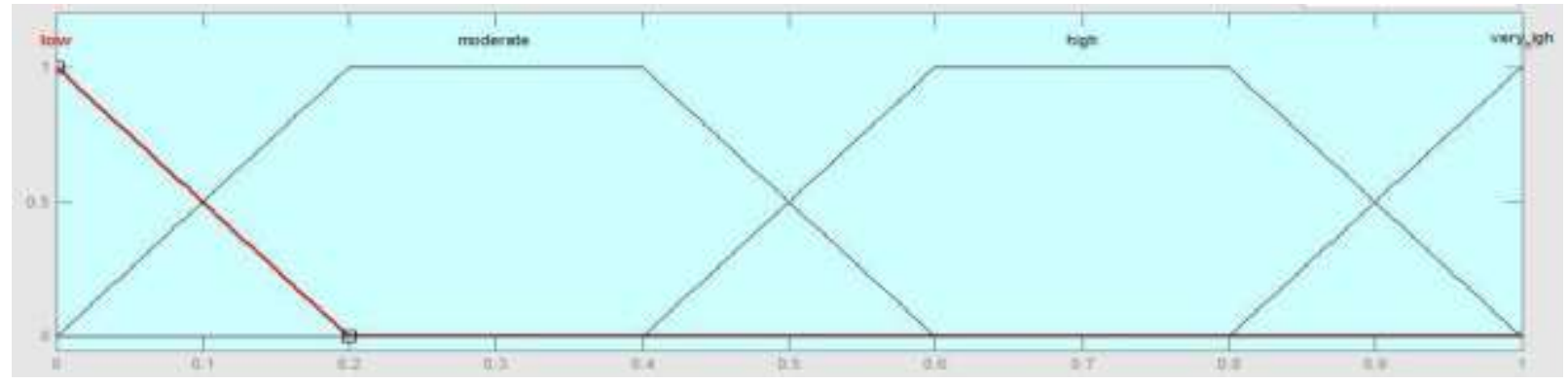

Figure 4. Membership Functions of Congestion Index 
Helix Vol. 8(5): 4029- 4033

\begin{tabular}{|c|l|l|l|l|l|l|l|}
\hline & & \multicolumn{7}{|c|}{ Travel speed rate } \\
\hline & & A & B & C & D & E & F \\
\hline \multirow{2}{*}{\begin{tabular}{c} 
Very $\begin{array}{l}\text { lows } \\
\text { peed rate }\end{array}$ \\
\cline { 2 - 8 }
\end{tabular}} & Low & Low & Low & Moderate & Moderate & High & High \\
\cline { 2 - 8 } & High & Low & Moderate & Moderate & High & High & V. High \\
\hline
\end{tabular}

Table II. Congestion Index Rules

Experimental Results

A real -world data of small area portion of Nagpur city were considered for this study and the two traffic measures namely travel speed rate and very- low speed rate were measured based on real-world data

\begin{tabular}{|c|c|c|c|c|c|c|c|c|c|}
\hline \multirow{2}{*}{$\begin{array}{l}\begin{array}{l}\text { Road- } \\
\text { way } \\
\text { link }\end{array} \\
\text { From }\end{array}$} & & \multicolumn{2}{|c|}{ TO Direction } & & \multicolumn{2}{|c|}{ FRO Direction } & \multirow[b]{2}{*}{$\begin{array}{l}\text { Congestion } \\
\text { Index (CI) }\end{array}$} & \multirow[b]{2}{*}{ Density } & \multirow[b]{2}{*}{$\begin{array}{l}\text { Congestion } \\
\text { Level }\end{array}$} \\
\hline & To & $\begin{array}{l}\text { Travel } \\
\text { speed } \\
\text { rate }\end{array}$ & $\begin{array}{l}\text { Very- } \\
\text { Low } \\
\text { Speed } \\
\text { Rate }\end{array}$ & $\begin{array}{l}\text { Congestion } \\
\text { Index (CI) }\end{array}$ & $\begin{array}{l}\text { Travel } \\
\text { speedrate }\end{array}$ & $\begin{array}{l}\text { Very- } \\
\text { Low } \\
\text { Speed } \\
\text { Rate }\end{array}$ & & & \\
\hline 1 & 2 & 0.284 & 0.24 & 0.29 & 0.286 & 0.24 & 0.29 & 0.45 & 0.62 \\
\hline 2 & 3 & 0.213 & 0.18 & 0.27 & 0.2 & 0.17 & 0.264 & 0.5 & 0.62 \\
\hline 3 & 4 & 0.318 & 0.28 & 0.299 & 0.318 & 0.28 & 0.299 & 0.55 & 0.62 \\
\hline 4 & 5 & 0.192 & 0.27 & 0.298 & 0.2 & 0.27 & 0.298 & 0.55 & 0.62 \\
\hline 1 & 9 & 0.191 & 0.04 & 0.064 & 0.189 & 0.04 & 0.064 & 0.6 & 0.44 \\
\hline 5 & 6 & 0.287 & 0.23 & 0.287 & 0.286 & 0.23 & 0.287 & 0.5 & 0.62 \\
\hline 6 & 7 & 0.255 & 0.21 & 0.281 & 0.259 & 0.21 & 0.28 & 0.6 & 0.62 \\
\hline 7 & 8 & 0.167 & 0.24 & 0.292 & 0.194 & 0.25 & 0.295 & 0.65 & 0.62 \\
\hline 2 & 9 & 0.192 & 0.13 & 0.213 & 0.182 & 0.12 & 0.184 & 0.4 & 0.58 \\
\hline 7 & 12 & 0.313 & 0.23 & 0.294 & 0.315 & 0.24 & 0.295 & 0.6 & 0.625 \\
\hline 8 & 14 & 0.304 & 0.22 & 0.291 & 0.3 & 0.21 & 0.289 & 0.7 & 0.625 \\
\hline 9 & 10 & 0.196 & 0.18 & 0.27 & 0.22 & 0.2 & 0.28 & 0.45 & 0.625 \\
\hline 9 & 15 & 0.124 & 0.13 & 0.238 & 0.13 & 0.12 & 0.208 & 0.5 & 0.625 \\
\hline 10 & 11 & 0.244 & 0.24 & 0.291 & 0.235 & 0.23 & 0.289 & 0.55 & 0.625 \\
\hline 12 & 13 & 0.192 & 0.27 & 0.298 & 0.2 & 0.27 & 0.298 & 0.2 & 0.475 \\
\hline 11 & 17 & 0.306 & 0.28 & 0.299 & 0.3 & 0.28 & 0.299 & 0.35 & 0.625 \\
\hline 12 & 18 & 0.293 & 0.27 & 0.297 & 0.286 & 0.26 & 0.295 & 0.4 & 0.625 \\
\hline 13 & 14 & 0.167 & 0.22 & 0.286 & 0.173 & 0.22 & 0.287 & 0.45 & 0.625 \\
\hline 15 & 16 & 0.207 & 0.16 & 0.257 & 0.195 & 0.15 & 0.247 & 0.7 & 0.625 \\
\hline 16 & 22 & 0.2 & 0.22 & 0.288 & 0.207 & 0.22 & 0.288 & 0.7 & 0.625 \\
\hline 17 & 19 & 0.333 & 0.28 & 0.299 & 0.315 & 0.27 & 0.297 & 0.6 & 0.625 \\
\hline 18 & 19 & 0.192 & 0.27 & 0.298 & 0.2 & 0.27 & 0.298 & 0.65 & 0.625 \\
\hline 19 & 20 & 0.207 & 0.22 & 0.288 & 0.225 & 0.23 & 0.29 & 0.25 & 0.544 \\
\hline 19 & 23 & 0.25 & 0.27 & 0.297 & 0.25 & 0.27 & 0.297 & 0.5 & 0.625 \\
\hline 20 & 21 & 0.234 & 0.22 & 0.286 & 0.213 & 0.21 & 0.284 & 0.3 & 0.625 \\
\hline 20 & 24 & 0.215 & 0.15 & 0.247 & 0.216 & 0.14 & 0.233 & 0.6 & 0.625 \\
\hline 21 & 27 & 0.263 & 0.31 & 0.333 & 0.286 & 0.31 & 0.333 & 0.75 & 0.625 \\
\hline 22 & 25 & 0.298 & 0.26 & 0.295 & 0.284 & 0.25 & 0.292 & 0.8 & 0.625 \\
\hline 22 & 23 & 0.323 & 0.27 & 0.298 & 0.367 & 0.3 & 0.353 & 0.55 & 0.625 \\
\hline 23 & 19 & 0.274 & 0.28 & 0.298 & 0.274 & 0.28 & 0.298 & 0.5 & 0.625 \\
\hline 24 & 25 & 0.118 & 0.09 & 0.073 & 0.12 & 0.08 & 0.074 & 0.6 & 0.454 \\
\hline 25 & 26 & 0.324 & 0.3 & 0.3 & 0.314 & 0.29 & 0.3 & 0.85 & 0.625 \\
\hline 26 & 30 & 0.226 & 0.19 & 0.275 & 0.231 & 0.2 & 0.28 & 0.85 & 0.625 \\
\hline 27 & 28 & 0.341 & 0.29 & 0.3 & 0.333 & 0.28 & 0.299 & 0.8 & 0.625 \\
\hline 28 & 29 & 0.318 & 0.3 & 0.3 & 0.323 & 0.3 & 0.3 & 0.85 & 0.625 \\
\hline 29 & 30 & 0.333 & 0.31 & 0.325 & 0.354 & 0.31 & 0.324 & 0.85 & 0.625 \\
\hline 30 & 31 & 0.286 & 0.31 & 0.333 & 0.263 & 0.31 & 0.333 & 0.8 & 0.625 \\
\hline
\end{tabular}

Table III. Congestion Index and Congestion Level Estimation 
Helix Vol. 8(5): 4029- 4033

\section{Conclusion}

The proposed approach considers the travel speed rate and the vary-low speed rate and produces a composite measure as Congestion Index. The fuzzy inference system is applied because possible errors in computation or measurement cause the individual values to be imprecise and the implication of the values with respect to the severity of congestion is ambiguous. The inference process is based on naturallanguage rules, which are consistent with the general feelings of the travellers. The proposed fuzzy controller is applied on real world datasets of Nagpur City, India for 31 signalized intersections and results are compared with highway capacity manual.

\section{References}

1. Kittelson, W. K., and R. P. Roess. 2001. Highway Capacity Analysis After the "Highway Capacity Manual" In Transportation Research Record: Journal of the Transportation Research Board, No. 1776, TRB, National Research Council, Washington, D.C., pp. 10- 16.

2. Khatib, Z. K., and M. Kyte. 2001. Uncertainty in Projecting Level of Service of Signalized and Unsignalized Intersections. Presented at the $80^{\text {th }}$ Annual Meeting of the Transportation Research Board, Washington, D.C.

3. Highway Capacity Manual. 2000. TRB, National Research Council, Washington, D.C. 